\title{
HIV testing among Canadian tuberculosis cases from 1997 to 1998
}

\author{
Tara Harris $\mathrm{MSc}^{1}$, Linda Panaro $\mathrm{MD}^{2}$, Melissa Phypers $\mathrm{MSc}^{3}$, Yogesh Choudhri $\mathrm{MD}^{4}$, Chris P Archibald $\mathrm{MD}^{4}$
}

\begin{abstract}
T Harris, L Panaro, M Phypers, Y Choudhri, CP Archibald. HIV testing among Canadian tuberculosis cases from 1997 to 1998. Can J Infect Dis Med Microbiol 2006;17(3):165-168.
\end{abstract}

BACKGROUND: Recent evidence suggests a global rise in adult tuberculosis (TB) cases associated with HIV/AIDS. The World Health Organization, the United States Centers for Disease Control and Prevention, and the Public Health Agency of Canada advocate universal screening of all TB cases for HIV. The contribution of HIV to the TB burden in Canada remains unclear.

METHODS: A retrospective cohort study was conducted of all TB cases reported in Canada from 1997 to 1998. The aim was to determine the proportion of patients that had an HIV test on record, and of these, the number of patients infected with HIV.

RESULTS: From 1997 to 1998, 3767 TB cases were reported to the national TB surveillance system. In the present study, 3416 case records $(90.7 \%)$ were included. The number of cases with a record of an HIV test was 736 (21.5\%), and of these, $41.2 \%$ were tested within one month of TB diagnosis. Among the 703 cases with known HIV test results, the prevalence of HIV infection was $14.7 \%$. Cases with an HIV test on record were more likely to have one or more risk factors for HIV, and also were more likely to be male, aged 15 to 49 years, of Aboriginal ethnicity, and to have smear-positive TB and both pulmonary and extrapulmonary disease at the time of diagnosis.

DISCUSSION: These results suggest that HIV testing of TB patients is not universal, but rather selective, and is likely based on perceived risk factors for HIV as opposed to TB diagnosis alone.

\section{Key Words: Coinfection; Epidemiology; HIV; Tuberculosis}

T he increasing global burden of tuberculosis (TB) disease has been related to HIV/AIDS. This is due to the fact that the risk of developing active TB disease among coinfected persons is $10 \%$ per year, making HIV the most potent risk factor for progression to active TB disease (1-3). Globally, TB is one of the leading causes of death among HIV-infected persons (4), and of all global adult TB cases aged 15 to 49 years, $9 \%$ are related to HIV/AIDS (5).

Despite close biological and epidemiological links between these two pathogens and increasingly coordinated efforts to address them concurrently, the uptake of new policies linking HIV and TB has been slow (6,7). For over 10 years, the Public Health Agency of Canada (PHAC) and the United States Centers for Disease Control and Prevention have recommended both universal HIV testing for newly diagnosed TB cases and TB assessment of all newly diagnosed HIV cases $(6,8)$. Despite these recommendations, the evidence suggests that universal testing for HIV among new TB cases has not been achieved (9). In Canada, the proportion of TB cases with HIV status

\section{Le dépistage du VIH dans les cas canadiens de tuberculose, de 1997 à 1998}

HISTORIQUE : Selon des données probantes récentes, on constaterait une augmentation mondiale du nombre de cas de tuberculose (TB) associés au VIH-sida chez les adultes. L'Organisation mondiale de la santé, les Centers for Disease Control and Prevention des États-Unis et l'Agence de santé publique du Canada préconisent le dépistage universel du VIH dans tous les cas de TB. La contribution du VIH au fardeau de la TB au Canada n'est pas claire.

MÉTHODOLOGIE : On a mené une étude de cohorte rétrospective auprès de tous les cas de TB déclarés au Canada de 1997 à 1998. Cette étude visait à déterminer la proportion de patients chez qui un test de dépistage du VIH était inscrit au dossier et le nombre de ces patients infectés par le VIH.

RÉSULTATS : De 1997 à 1998, 3767 cas de TB ont été déclarés au système national de surveillance de la TB. Dans la présente étude, 3416 dossiers de cas $(90,7 \%)$ ont été inclus. Sept cent trente-six cas $(21,5 \%)$ comportaient un test de dépistage du VIH en dossier. De ce nombre, 41,2\% avaient subi le dépistage dans le mois suivant le diagnostic de TB. Dans les 703 cas dotés de résultats connus du test de dépistage du VIH, la prévalence d'infection au VIH était de $14,7 \%$. Les cas comportant un test de dépistage du VIH en dossier étaient plus susceptibles de s'associer à au moins un facteur de risque du VIH, d'être de sexe masculin, d'avoir de 15 à 49 ans, d'être d'origine autochtone, d'avoir un frottis positif à la TB ainsi qu'une maladie à la fois pulmonaire et extrapulmonaire au moment du diagnostic.

DISCUSSION : D'après ces résultats, le test de dépistage du VIH chez les patients atteints de TB n'est pas universel mais plutôt sélectif, et il se fonde probablement sur les facteurs de risque perçus de VIH plutôt que sur le seul diagnostic de TB.

reported to the PHAC has increased from $5.7 \%$ to $17.3 \%$ between 1997 and 2002 but still falls far short of the recommendation of HIV testing for all TB cases (10).

Several published Canadian studies (11-14) have reviewed local and provincial data to estimate the degree of coinfection. Estimated rates of TB disease among AIDS cases range from $1.6 \%$ to $5.8 \%$, while studies conducted in Quebec (15) and British Columbia (16) estimated HIV coinfection among TB cases at $13.8 \%$ and $3.8 \%$, respectively. However, a comprehensive national picture of HIV coinfection among TB cases does not exist in Canada. The main objectives of the present study were to assess the extent of recorded HIV testing and the prevalence of coinfection among $\mathrm{TB}$ cases diagnosed in Canada from 1997 to 1998.

\section{METHODS}

The present study retrospectively examined reported cases of TB in Canada diagnosed from 1997 to 1998. Cases of TB disease in Canada are reported from the provinces and territories to the

\footnotetext{
${ }^{1}$ Ministry of Health and Long-Term Care, Government of Ontario; ${ }^{2}$ Field Epidemiology Training Program; ${ }^{3}$ Tuberculosis Prevention and Control;

${ }^{4}$ Surveillance and Risk Assessment Division, Public Health Agency of Canada, Ottawa, Ontario

Please see Appendix for provincial and territorial investigators

Correspondence: Dr Melissa Phypers, Tuberculosis Prevention and Control, Public Health Agency of Canada, Building \#6, Tunney's Pasture,

Address Locator 0603B, Ottawa, Ontario K1A OK9. Telephone 613-296-3500,fax 613-946-3902, e-mail Melissa_Phypers@phac-aspc.gc.ca Received for publication July 21, 2005. Accepted April 21, 2006
} 
TABLE 1

Factors associated with having an HIV test on record among tuberculosis (TB) cases in Canada from 1997 to 1998

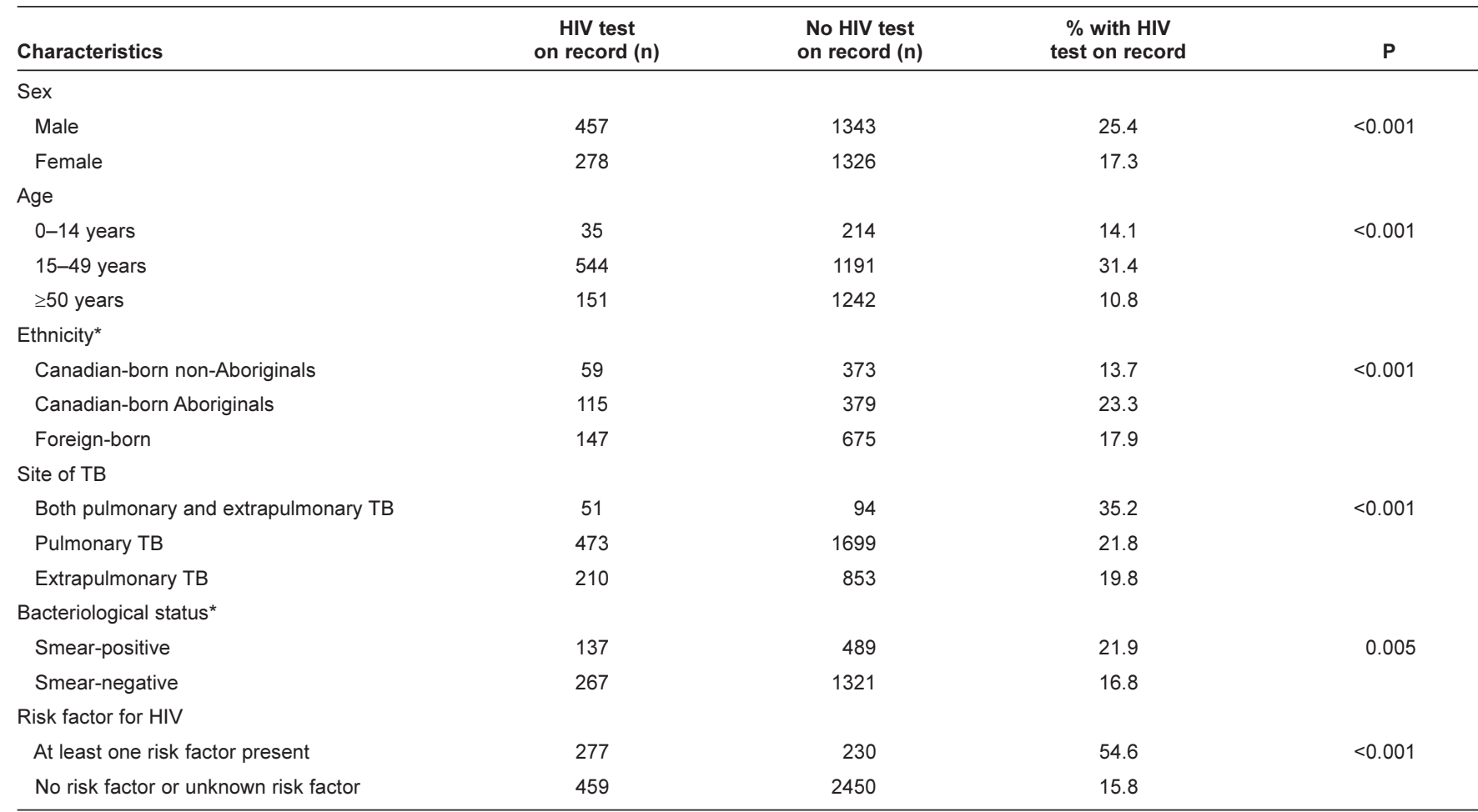

${ }^{*}$ Excludes data from Ontario

Division of Tuberculosis Prevention and Control at the PHAC, and are recorded in the Canadian Tuberculosis Reporting System (CTBRS). For the purpose of the present study, the CTBRS referred the 1997 and 1998 TB cases back to the provinces and territories with a standardized questionnaire for the completion of detailed case information, such as demographic data, country of birth, ethnic status (Aboriginal versus non-Aboriginal), site of TB disease, and date and result of any HIV testing.

For the purpose of the present analysis, cases were considered tested for HIV if there was a record of a test two years before or after TB diagnosis. All other cases were considered not tested, including cases where HIV testing may have been done but not recorded. If multiple tests were recorded, then the first positive test or closest negative test to the date of TB diagnosis was used.

To classify HIV risk among TB cases, the HIV risk group hierarchy was adapted from that used for HIV/AIDS surveillance in Canada (17). If multiple HIV risks were recorded, then cases were assigned to the single-risk category listed highest in the hierarchy.

Pearson $\chi^{2}$ tests were used to measure associations between demographic or clinical characteristics, and HIV testing. Levels of significance were examined using two-sided tests, and $\mathrm{P}<0.05$ was used to indicate statistical significance.

\section{RESULTS}

Between January 1, 1997, and December 31, 1998, 3767 cases of TB were diagnosed and reported to the CTBRS (18). The mean age of these patients was 43.5 years, and $2014(53.5 \%)$ were male. A total of $2423(64.3 \%)$ were foreign-born, $560(15 \%)$ were Canadian-born persons of Aboriginal ethnicity, and 748 (20\%) were Canadian-born persons of non-Aboriginal ethnicity (36 cases were of unknown birthplace). The diagnostic site of TB was respiratory in 2380 $(63.2 \%)$ of cases.
Information on HIV testing was received back from the provinces and territories for $3416(90.7 \%)$ of these cases, of which $736(21.6 \%)$ had a record of an HIV test on file and 703 had HIV status recorded. Thus, with further follow-up, a total of $18.7 \%$ (703 of 3767) of cases diagnosed in 1997 and 1998 had recorded HIV status compared with only 6\% on initial reports submitted to CTBRS. Among those whose HIV test results were recorded, HIV infection was noted in 103 of 703 cases $(14.7 \%)$.

To examine factors associated with HIV testing among TB cases, the group of cases with a recorded HIV test was compared with the group that had no record of an HIV test (Table 1). The most significant variable related to having an HIV test on record was the presence of at least one risk factor for HIV; $54.6 \%$ of this group had an HIV test on record compared with only $15.8 \%$ of the group with no HIV risk factors. Patients with an HIV test on record were also more likely to be male, aged between 15 and 49 years, of Aboriginal ethnicity, and to have smear-positive TB and both pulmonary and extrapulmonary disease at the time of diagnosis.

Among TB patients with a record of an HIV test on file and a record of the timing of the test, $41.2 \%$ were tested within one month of TB diagnosis, $27.9 \%$ were tested more than one month before TB diagnosis and 30.9\% were tested more than one month after the diagnosis of TB. The characteristics of patients tested at different times relative to the time of TB diagnosis are shown in Table 2. Smear-positive patients and patients with pulmonary site of TB were more likely to be tested at the time of TB diagnosis than were smear-negative patients or patients with other sites of TB. Very few persons aged zero to 14 years or Canadian-born non-Aboriginal persons (groups generally considered to be at low risk for HIV) were tested for HIV more than one month before TB diagnosis. 
TABLE 2

Factors associated with timing of HIV testing relative to time of tuberculosis (TB) diagnosis among TB cases in Canada from 1997 to 1998

\begin{tabular}{|c|c|c|c|c|}
\hline Characteristics & $\begin{array}{c}\text { Tested more than } \\
\text { one month before } \\
\text { TB diagnosis, } \\
n(\%)\end{array}$ & $\begin{array}{c}\text { Tested within } \\
\text { one month } \\
\text { of TB diagnosis, } \\
n(\%)\end{array}$ & $\begin{array}{c}\text { Tested more than } \\
\text { one month after } \\
\text { TB diagnosis, } \\
n(\%)\end{array}$ & $\mathbf{P}$ \\
\hline \multicolumn{5}{|l|}{ Sex } \\
\hline Male & $105(28.2)$ & $163(43.8)$ & $104(28)$ & \\
\hline Female & $65(27.2)$ & $90(37.7)$ & $84(35.1)$ & 0.15 \\
\hline \multicolumn{5}{|l|}{ Age } \\
\hline $0-14$ years & $4(12.5)$ & $20(62.5)$ & $8(25)$ & \\
\hline $15-49$ years & $120(27.4)$ & $182(41.6)$ & $136(31)$ & \\
\hline$\geq 50$ years & $46(33.8)$ & $48(35.3)$ & $42(30.9)$ & 0.05 \\
\hline \multicolumn{5}{|l|}{ Ethnicity* } \\
\hline Canadian-born non-Aboriginals & $4(12.9)$ & $21(67.7)$ & $6(19.4)$ & \\
\hline Canadian-born Aboriginals & $29(26.6)$ & $62(56.9)$ & $18(16.5)$ & \\
\hline Foreign-born & $26(25.7)$ & $49(48.5)$ & $26(25.7)$ & 0.21 \\
\hline \multicolumn{5}{|l|}{ Site of TB } \\
\hline Both pulmonary and extrapulmonary TB & $11(26.2)$ & $17(40.5)$ & $14(33.3)$ & \\
\hline Pulmonary TB & $102(25.6)$ & $191(48)$ & $105(26.4)$ & \\
\hline Extrapulmonary TB & $57(33.5)$ & $44(25.9)$ & $69(40.6)$ & $<0.001$ \\
\hline \multicolumn{5}{|l|}{ Bacteriological status* } \\
\hline Smear-positive & $27(27)$ & $60(60)$ & $13(13)$ & \\
\hline Smear-negative & $65(30.2)$ & $98(45.6)$ & $52(24.2)$ & 0.03 \\
\hline \multicolumn{5}{|l|}{ Risk factor for HIV } \\
\hline At least one risk factor present & $59(28)$ & $85(40.3)$ & $67(31.7)$ & \\
\hline No risk factor or unknown risk factor & $111(27.7)$ & $169(42.1)$ & $121(30.2)$ & 0.89 \\
\hline
\end{tabular}

${ }^{*}$ Excludes data from Ontario

\section{DISCUSSION}

The present study represents the first national assessment of HIV testing and TB/HIV coinfection among TB cases in Canada. HIV testing and counselling is the recommended standard of care for all patients that have been diagnosed with TB. However, the present study found that only $21.6 \%$ of TB cases diagnosed in Canada from 1997 to 1998 had a record of an HIV test on file. Although this proportion may be an underestimate of the actual proportion tested for HIV, because it excludes HIV testing that was not recorded in the chart, it is unlikely that universal HIV testing of $\mathrm{TB}$ cases is being achieved. This observation has been noted in other studies in Canada and elsewhere $(15,19,20)$. One-half of TB patients were not tested for HIV at TB diagnosis in Montreal, Quebec (15), and one-third of TB patients in Los Angeles (USA) were not tested for HIV (19). In the Los Angeles study (19), those having known risk factors for HIV were more likely to be tested, which is similar to what was found in the present study. A study of TB cases in North Carolina (USA) (20), from 1993 to 1999, found that approximately $34 \%$ of patients did not receive HIV testing; 19\% were not offered HIV testing and the remainder refused testing. Furthermore, older patients were significantly less likely to be offered HIV testing and more likely to refuse testing.

The estimate of HIV coinfection among Canadian TB cases in 1997 and 1998, calculated among those with known HIV status, is $14.7 \%$. However, this is likely an overestimate because results from the present study and others suggest that testing is selective and that persons at higher risk for HIV are more likely to be tested. If coinfection is calculated based on the entire cohort $(n=3416)$, then the estimated prevalence is $3 \%$, but this is certainly an underestimate. Therefore, the true prevalence of HIV among TB cases diagnosed in Canada during 1997 and 1998 is somewhere between 3\% and 14.7\%.

The low proportion of TB cases with recorded HIV tests in the present study represents a lost opportunity in terms of identifying unrecognized HIV infection, offering counselling to reduce further transmission of HIV and assessing the need for antiretroviral medication. McCarthy et al (21) found that the benefits from HIV screening outweigh the costs in populations where the HIV prevalence is greater than $0.5 \%$. Successful treatment of TB in HIV-infected persons can reduce morbidity and add approximately two years of life, as well as reduce future AIDS-related health care costs by approximately 50\% (22). Because our study found that at least $3 \%$ of reported TB cases were coinfected with HIV, screening of all TB cases for HIV would also be useful from a cost-benefit perspective.

The proportion of TB patients estimated to be HIV-positive varies over a wide range. In Canada, previous studies have found HIV prevalence rates among TB cases to range from less than 2\% in western Canada (23) to 3.8\% in British Columbia (16) and $13.8 \%$ in Quebec (15). However, none of these studies were national in scope. A TB/HIV record linkage, performed in the United States in 1999 with similar methods to the present study, found that $14 \%$ of TB cases reported to the Centers for Disease Control and Prevention from 1993 to 1994 were listed in the HIV/AIDS registries (24). A study in the United Kingdom (25) linked TB patients in the national TB database to patients in the HIV database, and found that $2.2 \%$ and 3.3\% of TB cases in 1993 and 1998, respectively, were 
coinfected with HIV. In developing countries, the variation is even more broad, depending on the prevalence of HIV infection in the general population; for example, less than $2 \%$ in India (26) and approximately $84 \%$ in Botswana (27) were coinfected with HIV.

HIV/TB coinfection has also been examined from the other perspective, that is, by examining the proportion of HIVinfected cases or of AIDS cases that have TB disease. National AIDS surveillance data in Canada indicate that 5.8\% (472 of 8087) of AIDS cases reported between 1994 and 2003 also had a diagnosis of TB (28). Factors associated with AIDS cases that had TB disease included being born outside of Canada, having Aboriginal ethnicity, and being an injecting drug user.

It should be noted that the data in the present study were incomplete in terms of HIV testing information and, thus, the extent of TB/HIV coinfection reported here should be interpreted with caution. The use of routine surveillance data for estimating TB/HIV coinfection in Canada is limited by the reporting characteristics of the current surveillance systems. Future directions could include studies that more accurately assess the extent of coinfection, by determining TB status in a representative sample of HIV-positive individuals or

\section{REFERENCES}

1. Selwyn PA, Hartel D, Lewis VA, et al. A prospective study of the risk of tuberculosis among intravenous drug users with human immunodeficiency virus infection. N Engl J Med 1989;320:545-50.

2. Pape JW, Jean SS, Ho JL, Hafner A, Johnson WD Jr. Effect of isoniazid prophylaxis on incidence of active tuberculosis and progression of HIV infection. Lancet 1993;342:268-72.

3. Hopewell PC. Impact of human immunodeficiency virus infection on the epidemiology, clinical features, management, and control of tuberculosis. Clin Infect Dis 1992;15:540-7.

4. Canadian Lung Association/Canadian Thoracic Society and Tuberculosis Prevention and Control, Centre for Infectious Disease Prevention and Control, Health Canada.

Canadian Tuberculosis Standards. < http://www.phacaspc.gc.ca/publicat/cts-ncla00/pdf/cts00.pdf>

(Version current at January 10, 2001).

5. Corbett EL, Watt CJ, Walker N, et al. The growing burden of tuberculosis: Global trends and interactions with the HIV epidemic. Arch Intern Med 2003;163:1009-21.

6. Canadian Tuberculosis Committee. Recommendations for the screening and prevention of tuberculosis in patients with HIV and the screening for HIV in tuberculosis patients and their contacts. Can Commun Dis Rep 2002;28(ACS-7):1-6.

7. Godfrey-Faussett P, Maher D, Mukadi YD, Nunn P, Perriens J, Raviglione M. How human immunodeficiency virus voluntary testing can contribute to tuberculosis control. Bull World Health Organ 2002;80:939-45.

8. Centers for Disease Control (CDC). Tuberculosis and human immunodeficiency virus infection: Recommendations of the Advisory Committee for the Elimination of Tuberculosis (ACET). MMWR Morb Mortal Wkly Rep 1989;38:236-8, 243-50.

9. Katz DJ, Hall WN, Keon NB, Crane LR. HIV testing in patients with tuberculosis. Physician response to national recommendations. Am Rev Respir Dis 1993;147:1283-6.

10. Public Health Agency of Canada. Tuberculosis in Canada, 2001. $<$ http://www.phac-aspc.gc.ca/publicat/tbcan01/pdf/tbcan_2001_e.pdf> (Version current at August 26, 2003)

11. Korzeniewska-Kosela M, FitzGerald JM, Vedal S, et al. Spectrum of tuberculosis in patients with HIV infection in British Columbia: Report of 40 cases. CMAJ 1992;146:1927-34.

12. Brassard P, Remis RS. Incidence of tuberculosis among reported AIDS cases in Quebec from 1979 to 1996. CMAJ 1999;160:1838-42.

13. Alexander DL. Epidemiology of AIDS/TB coinfection in Ontario 1990 to 1995. Public Health Epidemiol Rep Ont 1997;8:94-8.

14. Ofner M. Tuberculosis and AIDS in Ontario - A record linkage. Public Health Epidemiol Rep Ont 1993;4:330-3. determining HIV status among a representative sample of those with latent TB infection. Furthermore, follow-up studies should address attitudes within the medical profession toward universal testing to determine the reasons behind the inadequate compliance with the Canadian and international recommendations.

Universal HIV testing of TB cases should be encouraged to develop a more comprehensive picture of TB/HIV coinfection so that public health officials can deliver more effective treatment, care and prevention programs. Continued and enhanced surveillance of HIV prevalence among TB patients increases awareness of comorbidity, supports the development of joint TB/HIV policies and strategies, and can assist in targeting limited health care resources.

\section{APPENDIX \\ Provincial and territorial investigators}

Robert Remis, Kevin Elwood, Richard Long, Earl Hershfield, Vern Hoeppner, Lamont Sweet, Terry Nan Tannenbaum, Christofer Balram, Monali Varia, Maureen Baikie, Faith Stratton, Patricia Bleakley and Wanda White.

15. Geduld J, Brassard P, Culman K, Tannenbaum TN. Testing for HIV among patients with tuberculosis in Montreal. Clin Invest Med 1999;22:111-8.

16. Blenkush MF, Korzeniewska-Kozela M, Elwood RK, Black W, FitzGerald JM. HIV-related tuberculosis in British Columbia: Indications of a rise in prevalence and a change in risk groups. Clin Invest Med 1996;19:271-8.

17. Public Health Agency of Canada. HIV and AIDS in Canada: Surveillance Report to December 31, 2004. <http://www.phacaspc.gc.ca/publicat/aids-sida/haic-vsac1204/pdf/april_2005.pdf> (Version current at June 6, 2005).

18. Public Health Agency of Canada. Tuberculosis in Canada, 2002. <http://www.phac-aspc.gc.ca/publicat/tbcan02/pdf/tbcan_2002_e.pdf> (Version current at January 31, 2005).

19. Asch SM, London AS, Barnes PF, Gelberg L. Testing for human immunodeficiency virus infection among tuberculosis patients in Los Angeles. Am J Respir Crit Care Med 1997;155:378-81.

20. Stout JE, Ratard R, Southwick KL, Hamilton CD. Epidemiology of human immunodeficiency virus testing among patients with tuberculosis in North Carolina. South Med J 2002;95:231-8.

21. McCarthy BD, Wong JB, Munoz A, Sonnenberg FA. Who should be screened for HIV infection? A cost-effectiveness analysis. Arch Intern Med 1993;153:1107-16.

22. World Health Organization. TB and HIV - The deadly duo. <http://w3.whosea.org/LinkFiles/Tuberculosis_right6.pdf $>$ (Version current at April 27, 2006).

23. Cowie RL, Sharpe JW. Extra-pulmonary tuberculosis: A high frequency in the absence of HIV infection. Int J Tuberc Lung Dis 1997;1:159-62.

24. Moore M, McCray E, Onorato IM. Cross-matching TB and AIDS registries: TB patients with HIV co-infection, United States, 1993-1994. Public Health Rep 1999;114:269-77.

25. Rose AM, Sinka K, Watson JM, Mortimer JY, Charlett A. An estimate of the contribution of HIV infection to the recent rise in tuberculosis in England and Wales. Thorax 2002;57:442-5.

26. Solomon S, Anuradha S, Rajasekaran S. Trend of HIV infection in patients with pulmonary tuberculosis in south India. Tuber Lung Dis 1995;76:17-9.

27. Talbot EA, Hone NM, Moffat HJ, et al. The validity of HIV testing using sputum from suspected tuberculosis patients, Botswana, 2001. Int J Tuberc Lung Dis 2003;7:710-3.

28. Geduld JE, Archibald C. TB among reported AIDS cases in Canada: 1994 to 2003. Can J Inf Dis 2005;16(Suppl A):24A. 
Please note that the appendix in the article "HIV testing among Canadian tuberculosis cases from 1997 to 1998" by Harris et al (Can J Infect Dis Med Microbiol 2006;17[3]:165-168) was printed erroneously. Paul Rivest should have been listed rather than Terry Nan Tannenbaum. The authors regret the error. The corrected appendix is as follows:

APPENDIX

Provincial and territorial investigators

Robert Remis, Kevin Elwood, Richard Long, Earl Hershfield, Vern Hoeppner, Lamont Sweet, Paul Rivest, Christofer Balram, Monali Varia, Maureen Baikie, Faith Stratton, Patricia Bleakley and Wanda White. 


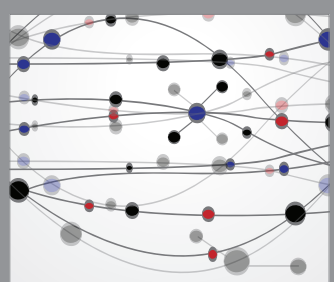

The Scientific World Journal
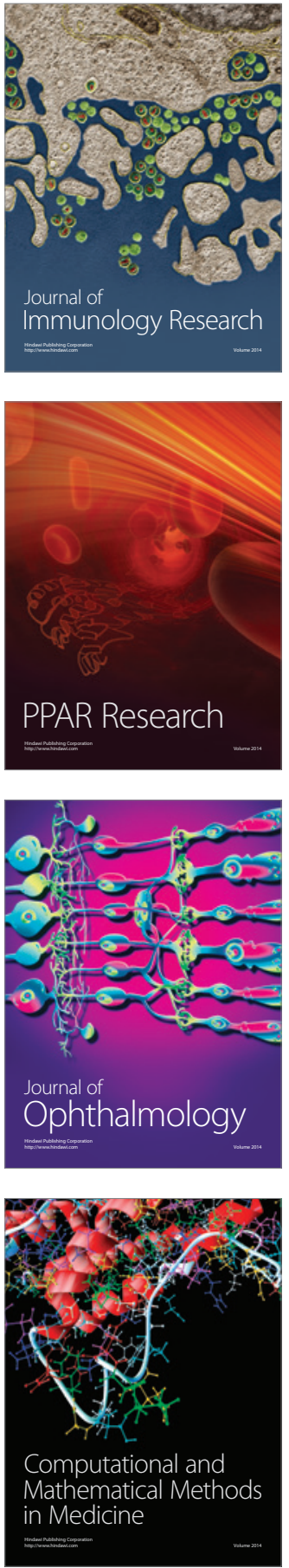

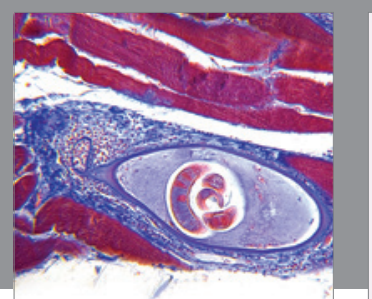

Gastroenterology Research and Practice

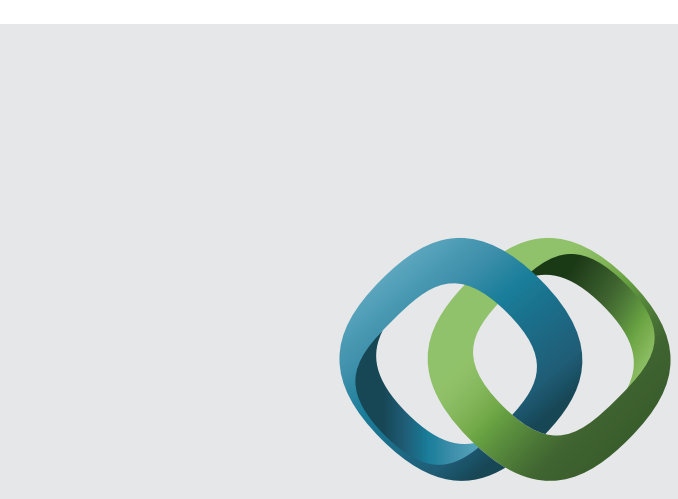

\section{Hindawi}

Submit your manuscripts at

http://www.hindawi.com
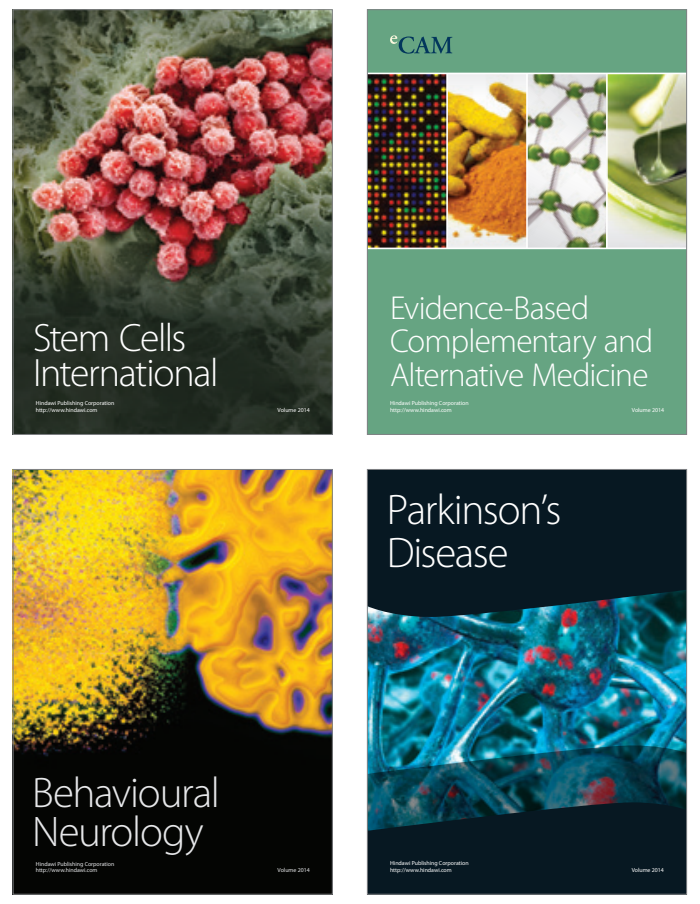
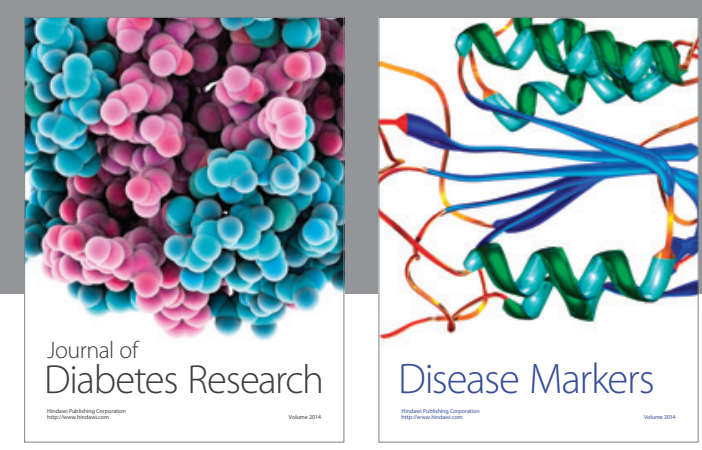

Disease Markers
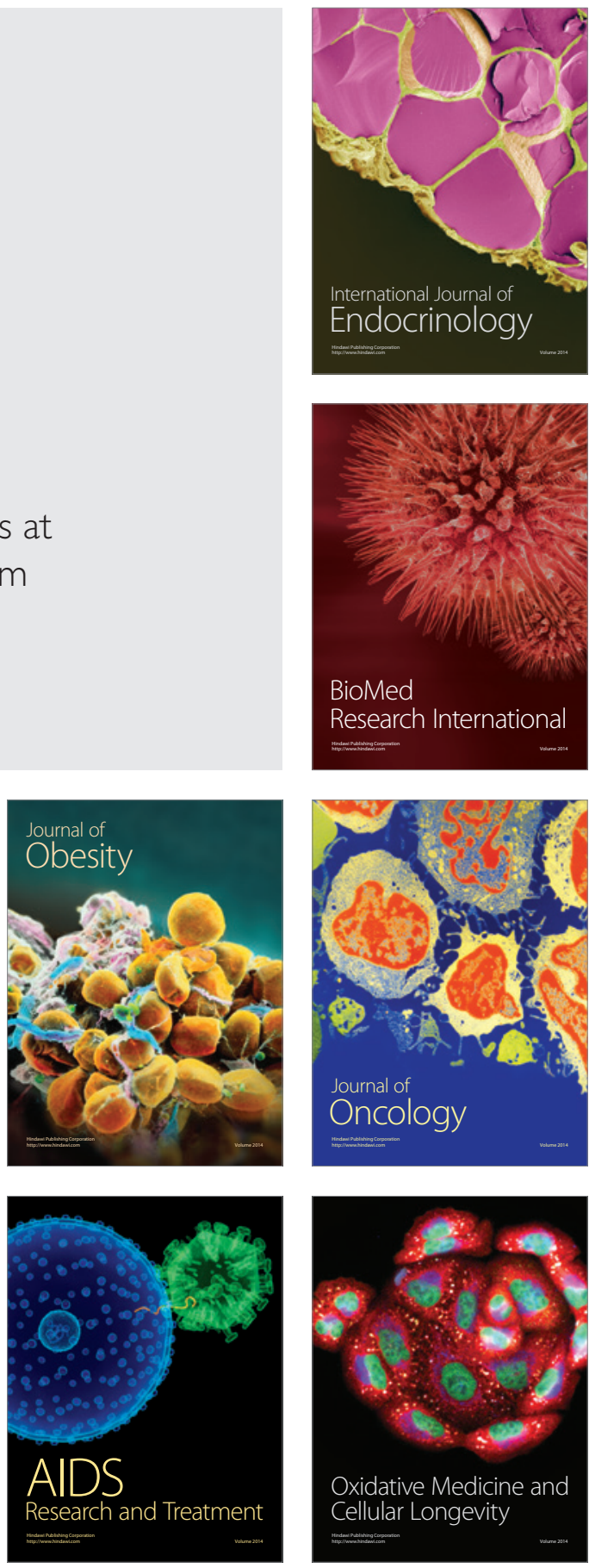